\title{
Nanocomposite Based on Calcium Hydroxyapatite and Ultrafine Graphite
}

L. I. Karbivska, S. S. Smolyak, V. L. Karbivskyy, D. A. Savchenko, A. O. Romansky, E. A. Pashchenko, and P. O. Teselko

\author{
G. V. Kurdyumov Institute for Metal Physics, N.A.S. of Ukraine, \\ 36, Academician Vernadsky Blvd., \\ UA-03142 Kyiv, Ukraine
}

Composites based on both nanodispersed calcium hydroxyapatite and ultrafine graphite are synthesized for the first time. The morphological features and electronic structure of the complexes are investigated. As revealed, the modification of a composite based on nanodispersed apatite, ultrafine graphite, cellulose fibres by means of the epoxy oligomer with a hardener has a significant effect on the complex properties of the material obtained, in particular, leads to the appearance of electrical conductivity of the sample. Two types of samples are obtained: I) composite of $\mathrm{Ca}_{10}\left(\mathrm{PO}_{4}\right)_{6}(\mathrm{OH})_{2}+$ graphite + cellulose fibres; II) composite of $\mathrm{Ca}_{10}\left(\mathrm{PO}_{4}\right)_{6}(\mathrm{OH})_{2}+$ graphite + cellulose fibres + epoxy oligomer. Electron scanning microscopy and x-ray photoelectron spectroscopy are used to study the structural features and electronic structure of the samples. Composite I is a connection, in which there are conductive and non-conductive components. Modification of the composite by means of the epoxy oligomer with a hardener leads to the appearance of electrical conductivity in the material. As shown, the addition of an epoxy oligomer makes minor change in the morphological parameters of the sample at the nanolevel. For composite II, an increase in the relative share of $\mathrm{C}=\mathrm{O}$ bonds in the total balance of carbon bonds is observed. The resulting composites have a high thermal stability inherent in hydroxyapatite and may be promising for use in a wide range of applications.

Вперше синтезовано композити на основі нанодисперсного гідроксоапатиту кальцію й ультрадисперсного графіту. Досліджено морфологічні особливості й електронну будову комплексів. Встановлено, що модифікування композиту на основі нанодисперсного апатиту, ультрадисперсного графіту, целюлозних волокон епоксидним олігомером із затверджувачем має істотний вплив на комплекс властивостей одержаного матеріялу, зокрема приводить до виникнення електропровідности зразка. Одержано зразки двох видів: I) композит $\mathrm{Ca}_{10}\left(\mathrm{PO}_{4}\right)_{6}(\mathrm{OH})_{2}+$ графіт + целюлозні волокна; II) композит $\mathrm{Ca}_{10}\left(\mathrm{PO}_{4}\right)_{6}(\mathrm{OH})_{2}+$ графіт +целюлозні волокна+епоксидний оліго- 
мер. Методами електронної сканувальної мікроскопії та рентгенівської фотоелектронної спектроскопії досліджено структурні особливості й електронну будову зразків. Композит I являє собою з'єднання, в якому присутні провідні та непровідні складові. Модифікування композиту епоксидним олігомером із затверджувачем приводить до появи електропровідности у матеріялу. Показано, що додавання епоксидного олігомеру мало змінюе морфологічні параметри зразка на нанорівні. Для композиту II спостерігається збільшення відносної частки зв'язків $\mathrm{C}=\mathrm{O}$ в загальному балансі зв'язків Карбону. Одержані композити мають високу термічну стійкість, властиву гідроксоапатиту, і можуть бути перспективними для використання в широкому спектрі застосувань.

Впервые синтезированы композиты на основе нанодисперсного гидроксоапатита кальция и ультрадисперсного графита. Исследованы морфологические особенности и электронное строение комплексов. Установлено, что модифицирование композита на основе нанодисперсного апатита, ультрадисперсного графита, целлюлозных волокон эпоксидным олигомером с отвердителем оказывает существенное влияние на комплекс свойств полученного материала, в частности приводит к возникновению электропроводимости образца. Получены образцы двух видов: I) композит $\mathrm{Ca}_{10}\left(\mathrm{PO}_{4}\right)_{6}(\mathrm{OH})_{2}+$ графит + целлюлозные волокна; II) композит $\mathrm{Ca}_{10}\left(\mathrm{PO}_{4}\right)_{6}(\mathrm{OH})_{2}+$ графит + целлюлозные волокна + эпоксидный олигомер. Методами электронной сканирующей микроскопии и рентгеновской фотоэлектронной спектроскопии исследованы структурные особенности и электронное строение образцов. Композит I представляет собой соединение, в котором присутствуют проводящие и непроводящие составляющие. Модификация композита эпоксидным олигомером с отвердителем приводит к появлению электропроводимости у материала. Показано, что добавление эпоксидного олигомера мало меняет морфологические параметры образца на наноуровне. Для композита II наблюдается увеличение относительной доли связей $\mathrm{C}=\mathrm{O}$ в общем балансе связей углерода. Полученные композиты имеют высокую термическую устойчивость, присущую гидроксоапатиту, и могут быть перспективными для использования в широком спектре применений.

Key words: composite, nanodispersed hydroxyapatite, ultrafine graphite, epoxy oligomer, current-conducting ceramics.

Ключові слова: композит, нанодисперсний гідроксоапатит, ультрадисперсний графіт, епоксидний олігомер, струмопровідна кераміка.

Ключевые слова: композит, нанодисперсный гидроксоапатит, ультрадисперсный графит, эпоксидный олигомер, токопроводящая керамика.

(Received 10 July, 2019)

\section{INTRODUCTION}

The development of technologies for producing new composite mate- 
rials based on calcium hydroxyapatite (HAP), a chemical analogue of the bone mineral, is primarily aimed at improving the properties of existing bioimplants based on HAP. When restoring bone, one of the important conditions is the electrical conductivity of the implant, which is necessary for the passage of electrical nerve impulses; that is why recently the main attention of researchers engaged in the synthesis and properties of composites based on HAP has been paid to the problem of high electrical conductivity. In addition, to obtain a composite, you can use either a polymer with high electrical conductivity, which is biotolerant, or various carbon materials. In addition to biomedical applications, HAP recently used in sensory and other microelectronic devices. Composites based on HAP and carbon materials have high thermal stability. Stoichiometric HAP is stable up to 1350 degrees Celsius. In the work of F. Chen et al. [1], based on hydroxyapatite nanowires, a design of electrically conductive paper was proposed. Since electronic devices are susceptible to the environment, for example, humidity, gas pollution or high temperature, the improvement of their applied properties, in particular electrical conductivity, remains a key condition for research in this direction. A number of publications are devoted to this problem, in particular, Refs. [1-6].

It is known, including from our works, that the native bone has a significant piezoelectric effect, which implies the use of composites based on calcium hydroxyapatite and ultrafine graphite as bone substitutes. In works [7-9], it was shown that external electrical stimulation of the damaged bone promoted progressive healing. In addition, the use of carbon nanomaterials, in particular, carbon nanotubes, significantly improves the mechanical properties of implants.

In this work, we synthesized composites based on nanodispersed calcium hydroxyapatite, ultrafine graphite, cellulose fibres, and conductive epoxy oligomer. Such composites are highly thermally stable and can be used for various medical and technical purposes.

\section{METHODS OF FABRICATION OF SAMPLES}

To obtain conductive samples of composites, the following basic reagents were used: 4-water crystal hydrate of calcium nitrate $\left(\mathrm{Ca}\left(\mathrm{NO}_{3}\right)_{2} \cdot 4 \mathrm{H}_{2} \mathrm{O}\right)$, 12-water crystal hydrate of acid salt of sodium phosphate $\left(\mathrm{Na}_{2} \mathrm{HPO}_{4} \cdot 12 \mathrm{H}_{2} \mathrm{O}\right)$, ammonia hydrate $\left(\mathrm{NH}_{4} \mathrm{OH}\right)$, cellulose fibres, ultrafine graphite, epoxy oligomer, hardener for epoxy oligomer.

The method of obtaining samples was as follows.

$\mathrm{Ca}\left(\mathrm{NO}_{3}\right)_{2} \cdot 4 \mathrm{H}_{2} \mathrm{O} 40 \mathrm{~g}$ and $\mathrm{Na}_{2} \mathrm{HPO}_{4} \cdot 12 \mathrm{H}_{2} \mathrm{O} 40 \mathrm{~g}$ separately dissolved in distilled water under heating. After dissolving, the solution 
$\mathrm{Na}_{2} \mathrm{HPO}_{4} \cdot 12 \mathrm{H}_{2} \mathrm{O}$ was added to the solution $\mathrm{Ca}\left(\mathrm{NO}_{3}\right)_{2} \cdot 4 \mathrm{H}_{2} \mathrm{O}$, wherein ammonia hydrate was added in parallel to maintain the acidity of no less than 10. After adding ammonia hydrate, the solution was left to warm for 1.5 hours with constant stirring, then, $10 \mathrm{~g}$ of ultrafine graphite and $4 \mathrm{~g}$ of cellulose fibres were added to the solution, following which the solution was left for another 24 hours without stirring and heating. As a result of the operations carried out during the specified time, precipitate was formed, namely, hydroxyapatite, the particles of which were located in the interfibre space of cellulose along with graphite particles. After the end of the 24-hour period, the resulting mass was filtered and dried.

From the dried mass of HAP + graphite + cellulose fibres in the fluoroplastic form, a sample of a given shape and size was formed. The sample was impregnated with a solution of epoxy resin and hardener and heated for 1 hour.

Two types of samples were obtained: I) composite $\mathrm{Ca}_{10}\left(\mathrm{PO}_{4}\right)_{6}(\mathrm{OH})_{2}+$ + graphite + cellulose fibres; II) composite $\mathrm{Ca}_{10}\left(\mathrm{PO}_{4}\right)_{6}(\mathrm{OH})_{2}+$ graphite + + cellulose fibres + epoxy oligomer.

To study these composite materials, we used the methods of scanning electron microscopy (SEM), x-ray photoelectron spectroscopy (XPS), energy dispersive x-ray spectroscopy (EDS).

$\mathrm{X}$-ray photoelectron spectra of the composites under study were obtained on a 'JSPM-4610' photoelectron spectrometer of the 'JEOL' company using non-monochromatic $\mathrm{Mg} K_{\alpha}(1253.6 \mathrm{eV})$ x-ray source. During the experiment, the vacuum in the analytical chamber was $10^{-7} \mathrm{~Pa}$, the accuracy of determining the electron binding energy was $0.1 \mathrm{eV}$. Due to the study of the conductive properties of the composites, upon receipt of the photoelectron spectra of the elements, gold was not deposited on the sample surface.
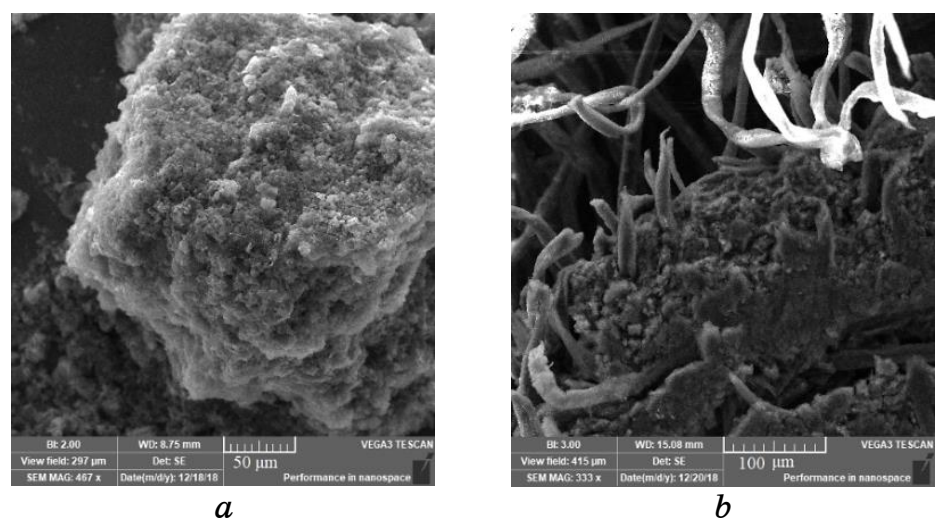

Fig. 1. SEM images of samples $\mathrm{Ca}_{10}\left(\mathrm{PO}_{4}\right)_{6}(\mathrm{OH})_{2}+$ graphite + cellulose fibres (a) and $\mathrm{Ca}_{10}\left(\mathrm{PO}_{4}\right)_{6}(\mathrm{OH})_{2}+$ graphite + cellulose fibres + epoxy oligomer $(b)$. 


\section{RESULTS AND DISCUSSION}

At low magnification in SEM images (Fig. 1), there is a significant difference in the morphology of the samples. The composite $\mathrm{Ca}_{10}\left(\mathrm{PO}_{4}\right)_{6}(\mathrm{OH})_{2}+$ graphite + cellulose fibres (Fig. 1, a) represents separate massive sphere-like fragments, while the presence of an epoxy oligomer in the structure of the second composite (Fig. 1, b) contributed to the formation of fibres that bind the particles.

With increasing resolution, one can observe the transformation of the morphological features of the samples (Fig. 2). As can be seen at $20 \mu \mathrm{m}$ scale (Fig. 2, $a, b$ ) in sample I, objects of a regular shape with a size of 1 to $10 \mu \mathrm{m}$ are observed, while the sample II shows an almost uniform morphological pattern over the entire surface under study. In some cases, on the samples of $\mathrm{I}^{\text {st }}$ type were clearly observed plates of various shapes with the above dimensions. The first sample is characterized by the presence of pores with sizes up to $1.5 \mu \mathrm{m}$. It is obvious that the presence of epoxy oligomer in

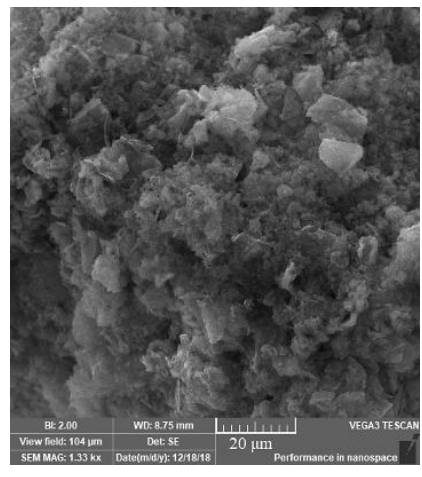

$a$

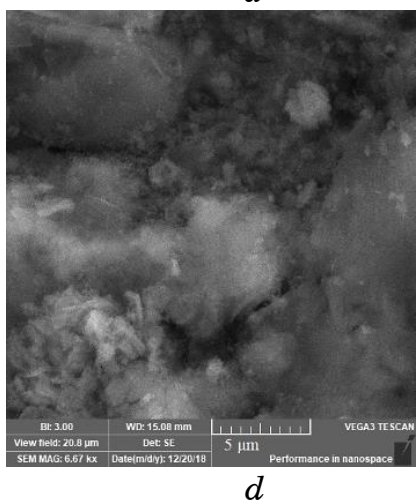

$d$

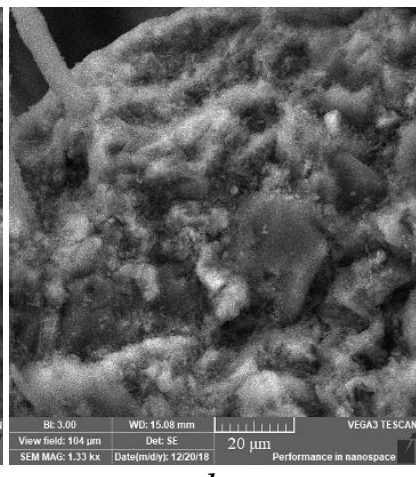

$b$

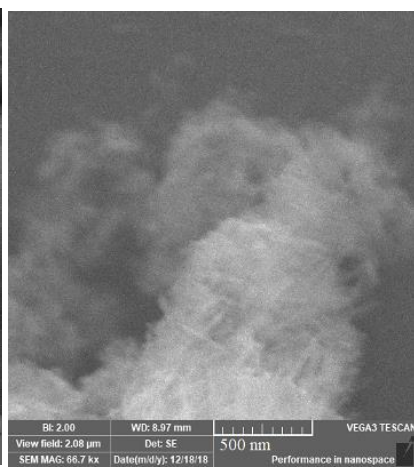

$e$
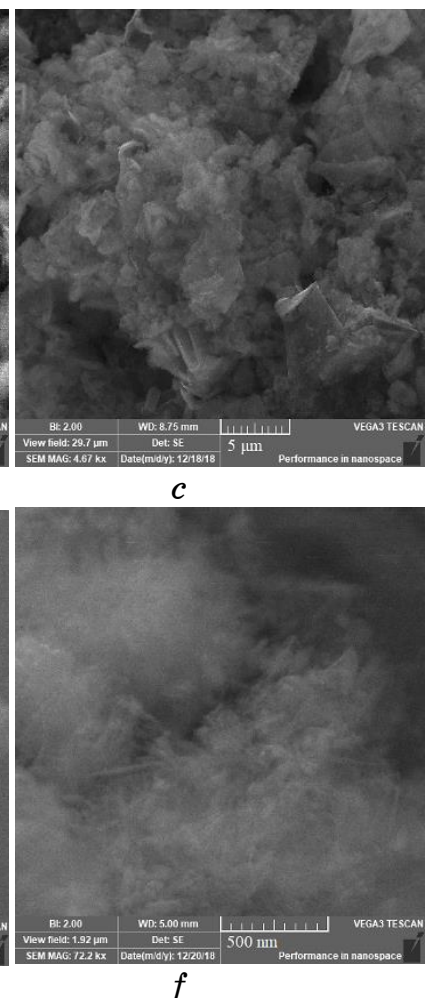

Fig. 2. SEM images of samples of $\mathrm{Ca}_{10}\left(\mathrm{PO}_{4}\right)_{6}(\mathrm{OH})_{2}+$ graphite + cellulose fibres $(a, c, e)$ and $\mathrm{Ca}_{10}\left(\mathrm{PO}_{4}\right)_{6}(\mathrm{OH})_{2}+$ graphite + cellulose fibres + epoxy oligomer $(b, d, f)$. 
the second sample leads to a continuous pattern without pores and clearly observed microobjects.

Turning to a larger increase (Fig. 2, $c, d$ ) in sample I, twodimensional objects with a size of up to $3 \mu \mathrm{m}$ are observed in detail. Oblong fibre-like inclusions with the same characteristic dimensions

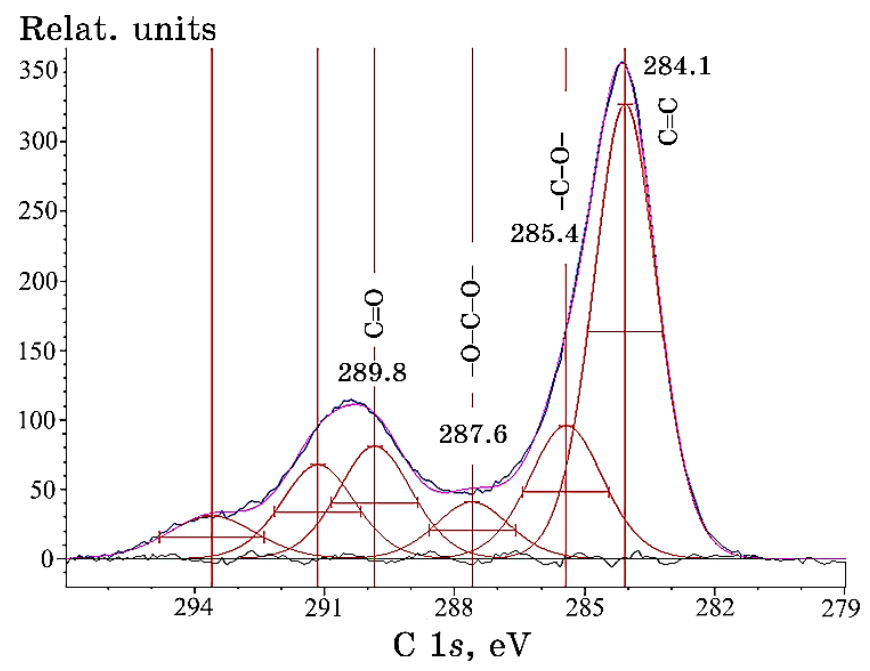

Fig. 3. C1s XPS-spectra of the sample $\mathrm{Ca}_{10}\left(\mathrm{PO}_{4}\right)_{6}(\mathrm{OH})_{2}+$ graphite + cellulose fibres.

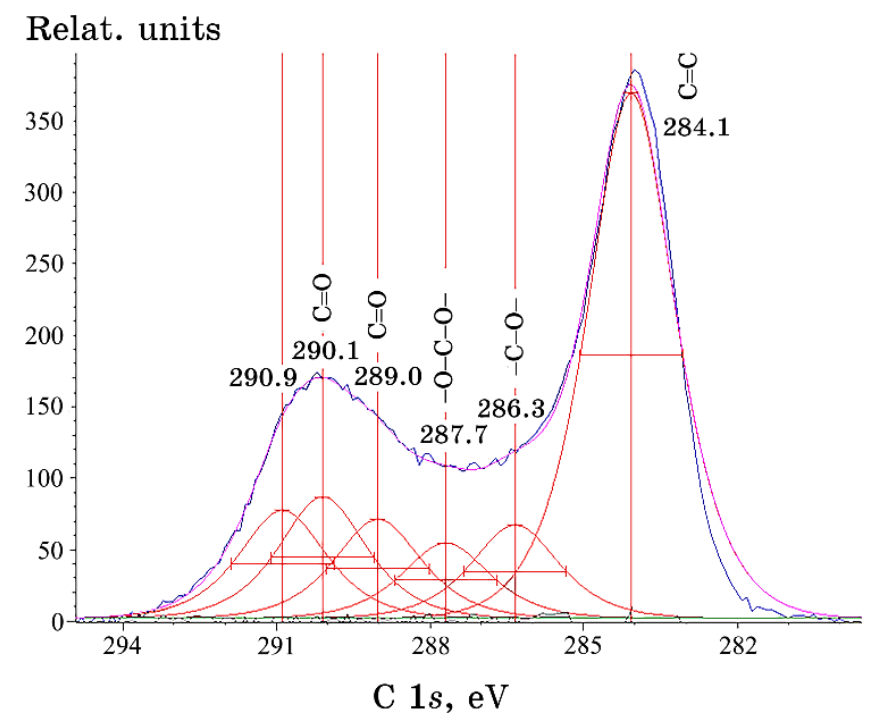

Fig. 4. C1s XPS-spectra of the sample $\mathrm{Ca}_{10}\left(\mathrm{PO}_{4}\right)_{6}(\mathrm{OH})_{2}+$ graphite + cellulose fibres + epoxy oligomer. 
also can be seen. At the same magnification, the second sample shows significant differences characterized by the monotony of the observed surface. However, at the same time, characteristic inclusions with a size of $1.0-2.0 \mu \mathrm{m}$ are observed in a considerable part of the surface. For the first sample, observation of pores with even smaller sizes is noteworthy.

At the nanolevel, both samples are characterized by the presence of fibres with a diameter of $\cong 20 \mathrm{~nm}$ and a length of up to $300 \mathrm{~nm}$. Consequently, the addition of an epoxy oligomer changes a little the morphological parameters of the second sample at the nanolevel.

Using the XPS method, it is found a significant difference in the electronic structure of the synthesized composites. A comparative analysis of the XPS spectra (see Figs. 3 and 4, which show the C1s spectra of both composites) showed that the samples contain $-\mathrm{C}-\mathrm{C}-$ bonds as well as bonds characteristic for complex carbon compounds of the $-\mathrm{C}-\mathrm{O}-$ and $\mathrm{C}=\mathrm{O}$ types.

The carbon spectra for a composite containing an epoxy oligomer have a more complex fine structure, since the epoxy oligomer contains a significant amount of different carbon bonds. The position of the components of the decomposition of the C1s electron spectra for both composites is given in Table.

The decomposition of the spectra into components was carried out with preservation of characteristic full width at half-maximum intensity for the corresponding carbon bonds. As can be seen from the experimental data, the number of $\mathrm{O}-\mathrm{C}-\mathrm{O}$ bonds (peaks around 287.6 $\mathrm{eV}$ ) for both samples remains almost the same. There is a greater variety of $\mathrm{C}-\mathrm{O}$ bonds for the first sample, which indicates a greater

TABLE. Binding energy $(\mathrm{eV})$ and full width at half-maximum intensity $(\mathrm{eV})$ of the core levels of atoms of the compounds at issue.

\begin{tabular}{c|c|c|c|c}
\hline Compound & $\mathrm{O} 1 s$ & $\mathrm{P} 2 p$ & $\mathrm{Ca} 2 p_{3 / 2}$ & $\mathrm{C} 1 s$ \\
\hline & & & & $284.1(1.7)-\mathrm{C}=\mathrm{C}-$ \\
Composite & & & & $285.4(2.0)-\mathrm{C}-\mathrm{O}-$ \\
$\left(\mathrm{Ca}_{10}\left(\mathrm{PO}_{4}\right)_{6}(\mathrm{OH})_{2}+\right.$ & 531.7 & 134.0 & 348.1 & $287.6(2.0)-\mathrm{C}-\mathrm{O}-$ \\
+ graphite + cellulose $)$ & $(3.9)$ & $(4.0)$ & $(3.0)$ & $289.8(2.0)-\mathrm{C}=\mathrm{O}$ \\
& & & & $291.2(2.0)-\mathrm{C}=\mathrm{O}$ \\
& & & & $293.6(2.3)$ satellite \\
& & & & $284.1(2.0)-\mathrm{C}=\mathrm{C}-$ \\
Composite & 532.2 & - & 347.3 & $287.3(2.0)-\mathrm{C}-\mathrm{O}-$ \\
$\left(\mathrm{Ca}_{10}(\mathrm{PO})_{6}(\mathrm{OH})+\right.$ & $(3.0)$ & & $(2.0)$ & $289.0(2.0)-\mathrm{C}=\mathrm{O}-$ \\
+ graphite + cellulose + & $(3.0)-\mathrm{O}-$ & $290.1(2.0)-\mathrm{C}=\mathrm{O}$ \\
+ epoxy oligomer $)$ & & & & $290.9(2.0)-\mathrm{C}=\mathrm{O}$ \\
& & & & - \\
$\mathrm{Ca}_{10}\left(\mathrm{PO}_{4}\right)_{6}(\mathrm{OH})_{2}$ & 531.2 & 133.3 & 347.3 &
\end{tabular}


variety of the local environment of carbon atoms.

At the same time, the number of non-bridged carbon bonds of the -C-O- type is significantly reduced in the second sample. This fact correlates with the change in the $\mathrm{O} 1 \mathrm{~s}$ line width in the second sample, that is $\cong 0.9 \mathrm{eV}$ less than in the first one. This indicates a
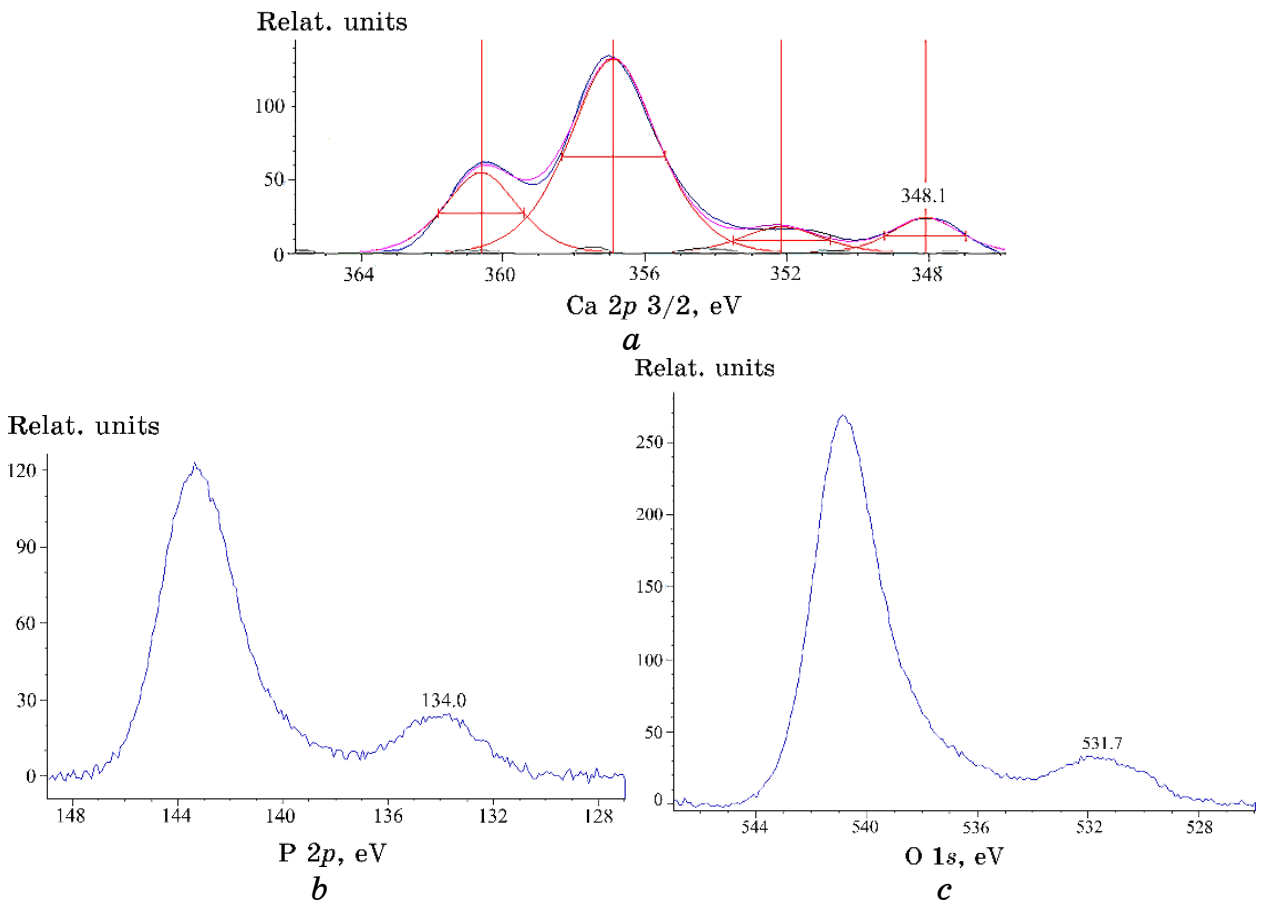

Fig. 5. XPS-spectra of the sample $\mathrm{Ca}_{10}\left(\mathrm{PO}_{4}\right)_{6}(\mathrm{OH})_{2}+$ graphite + cellulose fibres: (a) $\mathrm{Ca} 2 p$, (b) P2p, (c) $\mathrm{O} 1 s$.

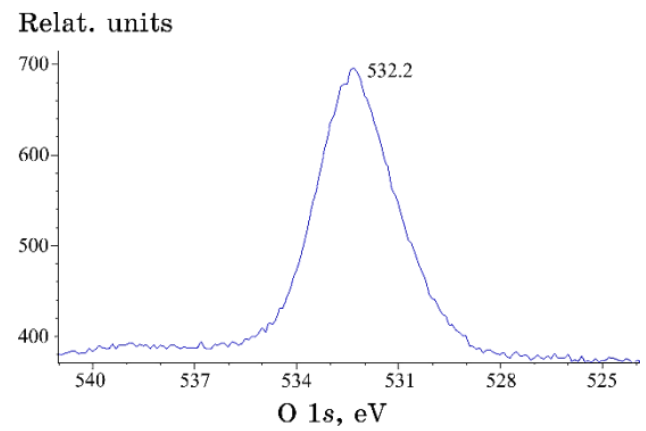

Fig. 6. O1s XPS-spectra of the sample $\mathrm{Ca}_{10}\left(\mathrm{PO}_{4}\right)_{6}(\mathrm{OH})_{2}+$ graphite + cellulose fibres + epoxy oligomer. 
greater structural ordering of carbon atoms.

In the second sample, an increase in the relative share of $\mathrm{C}=\mathrm{O}$ and $\mathrm{C}-\mathrm{O}$ bonds in the total carbon bond balance is observed. Based on the ratio of the experimental intensities of the peaks of $\cong 290.0$ $\mathrm{eV}$, it can be argued that the increase parameter is in the range from 1.3 to 1.4 . The peak at about $293.6 \mathrm{eV}$ in the first sample characterizes the satellite structure of the carbon spectrum. Its absence in the second sample indicates a significant change in the crystal field near carbon atoms. An increase in the number of decomposition components in the second sample also indicates an increase in the number of inequivalent carbon positions in the compound with the epoxy oligomer.

An analysis of the XPS data of both composites showed (Figs. 5, 6 , Table) that the presence of an oligomer in the composite structure leads to a redistribution of the charge of atoms. As seen from Table, modification of the composite with an epoxy oligomer leads to a decrease in the negative charge on oxygen and an increase in it on calcium atoms, which indicates a decrease in the ionic component of the chemical bond in the overall balance of the chemical bond.

It is noteworthy that for composite I, the x-ray photoelectron lines of the $\mathrm{Ca}, \mathrm{P}, \mathrm{O}$ elements have 'clones' and are shifted toward higher energies that indicates that the sample is charging during the process. Moreover, the intensity of doublet lines for the first sample is substantially higher. At the same time, XPS spectra of a composite with an epoxy oligomer do not have twinning of lines (see, for example, Fig. 6). This indicates that sample I contains both conductive fragments associated with graphite and fragments exhibiting the dielectric properties of hydroxyapatite. The SEM image of sample I obtained using energy dispersive x-ray spectroscopy confirms that carbon is unevenly distributed across the composite (Fig. 7 ). In the second sample, the presence of an epoxy oligomer provides the percolation effect of conductive areas and, consequently, the sample exhibits conductive properties.

The full width at half-maximum intensity of the spectrum of $\mathrm{Ca} 2 p$ for the studied compounds varies by almost 2 times. For stoichiometric calcium apatite, $\mathrm{Ca}_{10}\left(\mathrm{PO}_{4}\right)_{6}(\mathrm{OH})_{2}$, according to Table, it is $2 \mathrm{eV}$. At the same time, for the composite I, the full width at halfmaximum intensity of the Ca2 $p$ spectrum is $3.9 \mathrm{eV}$. Upon transition to composite II, the full width at half-maximum intensity decreases to $3.0 \mathrm{eV}$. This kind of result shows that nanodispersed calcium apatite having a large portion of calcium atoms on the surface, because of interaction during the synthesis of composites, forms a significant number of bonds leading to a large number of nonequivalent calcium positions. The presence of a significant amount of calcium on the surface of not only nanodispersed apatite, but al- 


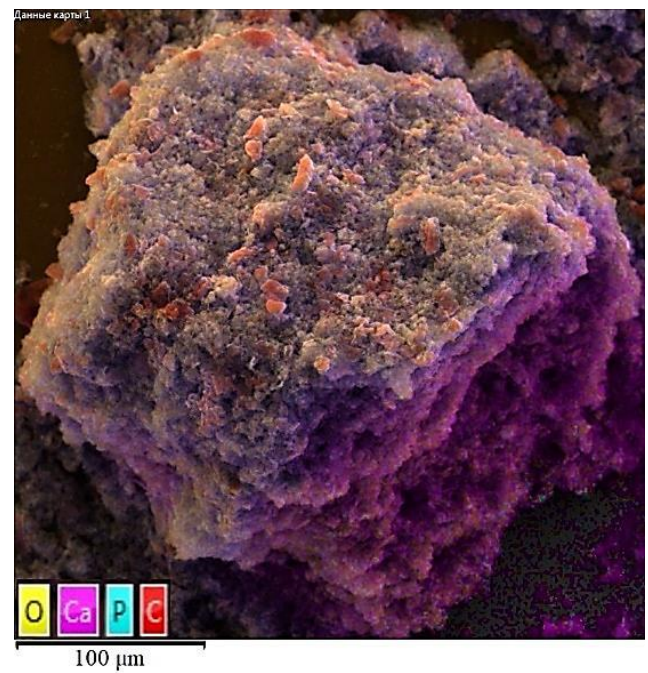

Fig. 7. SEM image of sample $\mathrm{Ca}_{10}\left(\mathrm{PO}_{4}\right)_{6}(\mathrm{OH})_{2}+$ graphite + cellulose fibres obtained using energy dispersive $\mathrm{x}$-ray spectroscopy.

so composites has been confirmed by electron-microscopy studies (Fig. 7). There is a significant crimson colour of the image, which, as indicated on the palette, is characteristic of oxygen. With the oligomerization of the first composite, a significant ordering and a decrease in the number of non-equivalent positions of calcium atoms are observed. Thus, in the second composite, the full width at halfmaximum intensity of the Ca2 $p$ spectrum is significantly reduced compared with composite I.

The positions of the maxima of the Ca2p spectrum for composite II and stoichiometric apatite coincide, while for composite I, there is a significant energy shift up to $0.8 \mathrm{eV}$ towards higher binding energies that indicates a significant offset of electron density from calcium atoms. With regard to the behaviour of the $01 s$ level maximums, a significant symbasis is noted.

During the transition to the composite, both position and width of the phosphorus line change significantly (Table) that is a consequence of the significant deformation of the phosphorus tetrahedra and, as a result, the presence of a significant amount of non-equivalent phosphorus positions, which affects the width of the P2 $p$ line.

\section{CONCLUSIONS}

Composites based on nanodispersed calcium hydroxyapatite and ultrafine graphite were synthesized for the first time. Two types of 
samples were obtained: I) composite $\mathrm{Ca}_{10}\left(\mathrm{PO}_{4}\right)_{6}(\mathrm{OH})_{2}$ + graphite + cellulose fibres; II) composite $\mathrm{Ca}_{10}\left(\mathrm{PO}_{4}\right)_{6}(\mathrm{OH})_{2}+$ graphite + cellulose fibres + epoxy oligomer. Electron scanning microscopy and x-ray photoelectron spectroscopy were used to study the structural features and electronic structure of the samples. Composite I is a compound, in which there are conductive and non-conductive components. Modification of the composite with an epoxy oligomer with a hardener leads to the appearance of conductivity in the material.

Composites have a different surface structure on almost all scales of the hierarchical structure. However, it was shown that the addition of an epoxy oligomer does not significantly change the morphological parameters of the sample at the nanolevel.

Analysis of the XPS data from both composites showed that the addition of graphite or/and epoxy oligomer significantly changes the charge states of atoms and the nature of the chemical bond in the sample. Adding an epoxy oligomer to the composite leads to a decrease in the negative charge on oxygen and an increase in the negative charge on calcium atoms that indicates a decrease in the ionic component of the chemical bond in the overall balance of the chemical bond.

In addition to $-\mathrm{C}-\mathrm{C}-$ bonds, $-\mathrm{C}-\mathrm{O}-$ and $\mathrm{C}=\mathrm{O}$ bonds' characteristics of complex carbon compounds are found in the compounds under study. For composite II, an increase in the relative share of $\mathrm{C}=\mathrm{O}$ bonds in the total balance of carbon bonds is observed.

Microscopic and XPS data showed the presence of a large number of both conductive and non-conductive sites in composite I. The presence of a percolation effect is revealed, which leads to a slight electrical conductivity of the composite I. Adding an epoxy oligomer to composite II contributes to the formation of much stronger bonds between the conductive fragments of the sample, and, therefore, composite II is much more uniform in conductivity and exhibits conducting properties. The resistive and reactive impedance of samples was measured by electrophysical methods.

The resulting composites have a high thermal stability inherent in hydroxyapatite and may be promising for use in a wide range of applications. Thus, it was found that modification of the composite based on nanodispersed apatite, ultrafine graphite, cellulose fibres with an epoxy oligomer with a hardener has a significant impact on the complex properties of the material obtained, in particular, leads to the appearance of electrical conductivity of the sample.

\section{REFERENCES}

1. F.-F. Chen, Y.-J. Zhu, Z.-C. Xiong, L.-Y. Dong, F. Chen, B.-Q. Lu, and R.-L. Yang, ACS Applied Materials \& Interfaces, 9, No. 45: 39534 (2017); 
DOI: 10.1021 /acsami.7b09484.

2. I. Tabiai, K. Chizari, V. Hughes, and T. Daniel, Technical Report, Report number: 11.2 (Montréal: École Polytechnique Montréal); DOI: 10.13140/RG.2.2.17004.16007.

3. $\quad$ A. Khosla and B. L. Gray, Materials Letters, 63: 1203 (2009); doi: 10.1016/j.matlet.2009.02.043.

4. A. Khosla, B. L. Gray, Macromol. Symp., 297: 210 (2010); doi:10.1002/masy.200900165.

5. A. Khosla, The Electrochemical Society Interface, 21: 67 (2012); doi: 10.1149/2.F04123-4if.

6. A. Shahini, M. Yazdimamaghani, K. J. Walker, M. Eastman, H. HatamiMarbini, B. Smith, J. L. Ricci, S. Madihally, D. Vashaee, and L. Tayebi, International Journal of Nanomedicine, 9: 167 (2014); DOI: https://doi.org/10.2147/IJN.S54668.

7. S. Constanda, M. S. Stan, C. S. Ciobanu, M. Motelica-Heino, R. Guégan, K. Lafdi, A. Dinischiotu, and D. Predoi, Journal of Nanomaterials, 2016: 1 (2016); http://dx.doi.org/10.1155/2016/3941501.

8. R. Rajesh, H. Ayyamperumal, S. Natarajan, and D. Ravichandran, International Journal of Pharmacy and Pharmaceutical Sciences, 4, No. 4: 716 (2012).

9. A. A. White, S. M. Best, and I. A. Kinloch, International Journal of Applied Ceramic Technology, 4, No. 1: 1 (2007); https://doi.org/10.1111/j.17447402.2007.02113.x. 